\title{
'Hey You? Get Off My Cloud': Evaluation of Cloud Service Models for Business Value within Pharma X
}

\author{
Rana Tassabehji ${ }^{1}$ and Ray Hackney ${ }^{2, *}$ \\ ${ }^{1}$ Bradford University, UK \\ ${ }^{2}$ Brunel University, London, UK
}

\begin{abstract}
Recent reports note that managers need to operate at the intersection of business and current innovative technology. Most notably, 'Strategy is not just informed by technology but powered by it'. The opportunity to evaluate aspects of 'cloud service models', as critical new systems, is therefore invaluable. Our research offers a pragmatic view of the characteristics of these technologies and a useful approach for identifying which may be most suitable in relation to the generation of business value. An example is provided of cloud service requirements within a multi-national pharmaceutical company (Pharma X) which is considered as a complex organizational context of significant interest. A highly qualitative methodological approach was adopted from personal interviews with a number of senior managers involved in new technology adoption. The extent of 'benefits', 'risks', 'when to use' and 'when not to use' were determined for a variety of common cloud service models to provide a schematic of important issues for evaluation and development. The research is insightful for large private sector multinational organisations which extends an analysis beyond the usual public sector studies. We conclude with lessons learned which demonstrate the most appropriate cloud enabled business models that support senior managers engaged in cloud service processes.
\end{abstract}

Keywords: Cloud services, pharmaceutical companies, models, business value.

\section{INTRODUCTION}

Our article outlines initially the broad features of cloud services and the types of systems available to managers. The context of a multi-national pharmaceutical is described which is considered a useful example of complex managerial environments. These further include a detailed perspective of the relevant and most appropriate approach facilitated by the three most common 'cloud' systems with the associated benefits and risks involved. The extent of advantages and disadvantages including when to adopt and not to adopt are also described. Overall, a valuable contribution is made for the implementation of these systems for business value. We conclude with lessons learned from our research and suggestions for further analysis.

A developing consensus of the definition of cloud computing is based on the US National Institute of Standards and Technology, i.e.;

"Cloud computing is a model for enabling ubiquitous, convenient, on-demand network access to a shared pool of configurable computing resources (e.g., networks, servers, storage, applications, and services) that can be rapidly provisioned and released with minimal

*Correspondence Address to this author at the Brunel University London, UK; Tel: +44 (0)1895 274000; E-mail: ray.hackney@brunel.ac.uk

\section{management effort or service provider interaction." [12]}

Recent innovations in 'cloud services' enable significant managerial and technical advantages in facilitating and sharing information within a variety of complex organizational contexts [1, 3, 4, 5, 10, 16]. Mell and Grance [12] identify three core service levels (i) Platform-as-a-Service (PaaS) where the consumer can deploy onto the cloud infrastructure their own applications supported by the provider, although they do not manage the infrastructure they do have control over the applications (ii) Software-as-a-Service (SaaS) where applications can be accessed via various client devices by consumers through the cloud infrastructure, and the consumer has no control and does not manage the infrastructure delivering the software (iii) Infrastructure-as-a-Service (laaS) where the consumer can provision processing, storage, networks and other computing resources (including operating systems and applications) and has control over these, but does not manage or control the underlying cloud infrastructure.

The benefits of cloud computing may also include (i) on-demand self-service, where a consumer can access computing capabilities automatically when required with no human interaction (ii) broad network access, where computing capabilities/services can be accessed through a range of interfaces and devices (mobile, laptop, tablets) over the network (iii) resource polling where the cloud computing provider resources (memory, processing, bandwidth, storage) are pooled 
to serve multiple customers dynamically assigned and re-assigned on demand, independent of location (iv) rapid elasticity where consumers can access 'unlimited' capabilities in any quantity and at any time through the cloud which can provision and release these, scaled inward or outward, dependent on demand ( $v$ ) measured services, where cloud systems automatically control and optimize resources using a metering capability which provides transparency to provider and consumer of the services utilized $[6,7]$.

According to Google Trend [9] the SaaS model is the most widely adopted model compared to laaS and PaaS which are still relatively immature, but are projected to grow to higher levels than SaaS and PaaS respectively. Reza [14] recommends that a service of high value to the organization and low complexity should be immediately moved to laas in the Private Cloud. Services that can be improved with limited developer or limited computing resources should adopt the PaaS model. New services that are required to be implemented quickly and have an available budget and software service should look into implementing SaaS, for instance webmail, office productivity software and CRM software. While this framework provides a good foundation for evaluating the adoption of cloud computing in any organization, one of the weaknesses of the model is that it does not provide details of the general requirements for classifying service criteria which can be applied empirically.

\section{CASE CONTEXT: THE PHARMACEUTICAL SECTOR AND CLOUD SERVICE EVALUATION}

The case site was a large multinational pharmaceutical (Pharma X) organisation who note their function is, '..... to push the boundaries of science to deliver life-changing medicines'. The company has a long history of significant scientific innovation that involves many years of drug discovery successes. The main objective of course is to enhance the life chances of patients around the world through the development and availability of modern effective medical treatments. Pharma $X$ has a workforce of nearly 7000 based within the UK and some 30000 worldwide. Globally, Pharma $X$ focus on six key therapeutic areas which potentially make the most difference: cancer, infection, cardiovascular diseases and diabetes, gastrointestinal, neuroscience and respiratory medicine.

For the purpose of our research the case site offered the opportunity for a rich qualitative evaluation of new systems which support their company strategy. It is evident that many previous studies have a public sector focus, i.e. health sector, etc [16] while our research presents findings from an alternative cultural environment. Our approach therefore is extensively informative based upon managerial consultancy experience. We have avoided too much emphasis upon a rigorous theoretical foundation in an attempt to provide insightful 'perceptions' of new technology adoption in the light of mature observations. Key stakeholders were therefore selected to better understand business and technical requirements namely, (i) Corporate end users, who will use the service or applications hosted on the Cloud Computing platform; (ii) Cloud Computing Architects who understand, analyse and document the functional and non-functional requirements and interact with Service Providers (iii) Cloud Computing service providers who understand the requirements and provide options for Cloud computing Service Models. In total 14 managers were interviewed across a broad spectrum of roles involved in end-to-end IT project implementation including the IT development teams, users and engineers within Pharma $X$ and for the external development team. This was achieved through a series of semi-structured open-ended data collection techniques (Expert Interview Template) which allowed the opportunity for descriptive comments on cloud service features and experiences of their implementation. For instance, respondents were asked to provide a definition of cloud computing and future trends for its use; experience of different kinds of service models (PaaS; SaaS;CaaS; MaaS; ELaaS; BPaaS), which of these were most widely used, how and by whom, requirements of cloud computing; implications of introducing each of these models on existing applications (desktop and high end apps), benefits and drawbacks of different cloud service models and key implementation decision making.

The empirical data suggests that SaaS is the most popular model of cloud computing followed by laaS and to a lesser extent PaaS. However a myriad of factors such as company size, industry (including regulations and compliance), markets, organizational strategies, budgets impact the decision for selecting the most appropriate service and it is not yet clear which of these models is the most appropriate in different contexts. Figure 1 summarises the comparative benefits and risks of the three main models of cloud computing relative to Pharma $X$ which is clearly generalizable for other sectors.

There are also risks associated with cloud service activities, some of which have been evident from other 


\begin{tabular}{|c|c|c|}
\hline $\begin{array}{l}\text { Cloud Computing } \\
\text { Model }\end{array}$ & Benefits & Risks \\
\hline $\begin{array}{l}\text { Infrastructure-as-a- } \\
\text { Service (IaaS) } \\
\text { e.g. } \\
\text { Amazon EC2, Zenith's } \\
\text { Proud }\end{array}$ & $\begin{array}{l}\text { - Reduced capital costs } \\
\text { - Global accessibility } \\
\text { - Flexibility and scalability multiple location access and on } \\
\text { demand capacity } \\
\text { - Standardisation of products/services } \\
\text { - Automatic system upgrades and management } \\
\text {-Offers full control of server infrastructure } \\
\text { - Not restricted to "containers" or "applications" }\end{array}$ & $\begin{array}{l}\text {-Vendor lock-in } \\
\text {-Dependent on IaaS provider. } \\
\text {-Data security of private/sensitive data } \\
\text { - Local hosting data regulations } \\
\text { - Sometimes comes with a price premium } \\
\text {-Infrastructure offerings still being built }\end{array}$ \\
\hline $\begin{array}{l}\text { Platform-as-a-Service } \\
\text { (PaaS) } \\
\text { e.g. } \\
\text { Google App engine; } \\
\text { LongJump, } \\
\text { Force.com, Wolf PaaS, } \\
\text { Windows Azure, etc. }\end{array}$ & $\begin{array}{l}\text {-Multiple platform components available } \\
\text { - Provides Platform to deploy, test, host and maintain } \\
\text { application in the same integrated environment } \\
\text {-Enables multiple users concurrently using the same integrated } \\
\text { application development environment } \\
\text { - pay per use pricing model } \\
\text { - Reduced capital costs } \\
\text {-Built in scalability and elasticity for efficient management of } \\
\text { load and usage } \\
\text {-Enables rapid deployment of applications } \\
\text {-Enables team-working across geographically distributed } \\
\text { locations }\end{array}$ & $\begin{array}{l}\text {-Security of data } \\
\text { - Lack of bandwidth or network connectivity } \\
\text { could lead to slow/no cloud access } \\
\text { - Interface standardisation is not well defined } \\
\text { across multiple cloud service providers } \\
\text {-Vendor lock in } \\
\text {-Portability when switching cloud service } \\
\text { provider } \\
\text {-Dependency on single Cloud provider means } \\
\text { any outage of the hosting provider will cause } \\
\text { outage for the platform }\end{array}$ \\
\hline $\begin{array}{l}\text { Software-as-a-Service } \\
\text { (SaaS) } \\
\text { e.g. } \\
\text { Gmail, Facebook, } \\
\text { SalesForce.com, Zoho } \\
\text { CRM, etc. }\end{array}$ & $\begin{array}{l}\text { - No client or server software installation or maintenance } \\
\text { required } \\
\text { - Shorter deployment times } \\
\text { - Global availability } \\
\text { - Service Level Agreement (SLA) adherence } \\
\text { - Constant, Smaller, Upgrades } \\
\text { - Reduced IT staff - only IT staff required to configure } \\
\text { applications } \\
\text {-Enables redistribution of resources: IT budget and personnel to } \\
\text { focus on core competencies or reallocated to boost productivity } \\
\text {-Easy to use, customise and access } \\
\text {-Multiple offerings } \\
\text {-Proven and successful business models }\end{array}$ & $\begin{array}{l}\text {-Identity management might be problematic } \\
\text { with multiple client users } \\
\text { - Governance and compliance issues as } \\
\text { physical location of the servers hosting } \\
\text { software might not be known. } \\
\text {-Access to software over internet increases risk } \\
\text { of hacking and virus attacks } \\
\text { - Cloud standards not well defined } \\
\text { - Security of data because of multiple clients } \\
\text { - No control over applications }\end{array}$ \\
\hline
\end{tabular}

Figure 1: Comparative Benefits and Risks of Cloud Computing Models.

outsourcing projects [17, 19]. For instance, lack of business continuity and service availability if there are outages in cloud provision particularly if there is only one sole provider, but this could be overcome by using the ISP model of multiple network providers [3]. Other obstacles include data lock-in which makes it difficult for users to extract or move their data, potential performance unpredictability of virtual machines (VMs) and data confidentiality and auditability which are the most often cited risks for cloud users [18, 19]. The mapping of these service models for the pharmaceutical case company are summarised in Figure 2.

There was a clear mandate from the case study organization to implement cloud computing for several reasons including cost reduction, improving process efficiency and effectiveness provided through the consolidation of IT systems and to reduce implementation times.

\section{LESSONS LEARNED}

Typically in a cloud implementation planning phase for any service model, a detailed assessment of the application must be carried out with a view to understanding if the application is appropriate for migrating into the Cloud [20]. The next stage for these candidate cloud applications is a detailed Return on Investment (ROI) and Total Cost of Ownership (TCO) to be carried out in order to understand the full cost benefits that will be achieved from the Cloud compared to the conventional IT deployments. The appropriate service model needs to be chosen and the business case should include all the key considerations including technical benefits, cost comparison, timeline reductions etc. before any analysis can be presented by the technical teams to the senior management for taking any decision.

The theoretical foundations for cloud service evaluation are also well documented. Armbrust et al. $[3,8,9]$ present three particularly compelling economic cases in favour of cloud computing that benefit organizations for business value. Firstly there is a considerable reduction in fixed costs where capital expenses are converted to operating expenses (CapEx to OpEx) or the 'pay-as-you-go' model which captures the economic benefits to the buyer. As more and more 


\begin{tabular}{|c|c|c|c|c|c|c|}
\hline $\begin{array}{l}\text { Service } \\
\text { Model }\end{array}$ & Characteristics & Key terms & \begin{tabular}{|l|} 
Advantages in \\
Pharmaceutical industry
\end{tabular} & $\begin{array}{l}\text { Disadvantages and risks in } \\
\text { Pharmaceutical industry }\end{array}$ & When to use & When not to use \\
\hline laas & $\begin{array}{l}\text { Infrastructure as } \\
\text { a service } \\
\text { End-user pay for } \\
\text { OS instance } \\
\text { Application } \\
\text { license paid by } \\
\text { End-user }\end{array}$ & $\begin{array}{l}\text { Usually platform independent } \\
\text { Infrastructure are shared and } \\
\text { thus reduction in costs } \\
\text { SLAs for the Infrastructure } \\
\text { Pay as you use } \\
\text { Scalability is good }\end{array}$ & \begin{tabular}{|l|} 
Reduction in upfront \\
costs \\
Can be accessed from \\
anywhere in the world \\
Scalability on demand \\
Standardisation \\
Automatic system \\
upgrades
\end{tabular} & $\begin{array}{l}\text { Compliance issues } \\
\text { Security is another major } \\
\text { concern } \\
\text { Vendor Lock in } \\
\text { Availability is dependent } \\
\text { on the service provider }\end{array}$ & $\begin{array}{l}\text { Initial application } \\
\text { development and } \\
\text { testing } \\
\text { Performance testing } \\
\text { using dummy or } \\
\text { scrambled data }\end{array}$ & $\begin{array}{l}\text { Critical applications } \\
\text { which hold } \\
\text { production } \\
\text { confidential data } \\
\text { Applications with } \\
\text { compliance } \\
\text { requirements } \\
\end{array}$ \\
\hline Paas & \begin{tabular}{|l|} 
Platform as a \\
Service \\
Infrastructure \\
with platform is \\
provided by the \\
Service Provider
\end{tabular} & $\begin{array}{l}\text { Saving on platform license } \\
\text { costs } \\
\text { Infrastructure and Platform } \\
\text { supported by Service Provider }\end{array}$ & $\begin{array}{l}\text { Multiple platform can be } \\
\text { offered as a service } \\
\text { Can be treated as } \\
\text { Integrated Env } \\
\text { Scalability of users } \\
\text { Lower licensing and } \\
\text { TCO costs } \\
\text { Rapid deployment } \\
\text { Can be accessed over } \\
\text { internet from anywhere } \\
\text { in the world }\end{array}$ & $\begin{array}{l}\text { Security } \\
\text { Dependency on the } \\
\text { network links for } \\
\text { availability and } \\
\text { performance } \\
\text { Interface standardisation } \\
\text { is not well defined } \\
\text { Vendor lock in } \\
\text { Dependency on single } \\
\text { cloud provider }\end{array}$ & $\begin{array}{l}\text { Possible use could be } \\
\text { Marketing division } \\
\text { using Salesforce } \\
\text { force.com }\end{array}$ & $\begin{array}{l}\text { Critical applications } \\
\text { which needs to be } \\
\text { accessed } 24 \times 7365 \\
\text { days } \\
\text { Applications holding } \\
\text { confidential data } \\
\end{array}$ \\
\hline SaaS & \begin{tabular}{|l|} 
\\
Software as an \\
Service \\
Also referred as \\
Application as a \\
Service \\
\end{tabular} & $\begin{array}{l}\text { Saving on Infrastructure, } \\
\text { Platform and application } \\
\text { development license and } \\
\text { costs } \\
\text { Shared application is used by } \\
\text { a end used mostly using a } \\
\text { username and password }\end{array}$ & \begin{tabular}{|l|} 
No Client or server \\
installation required \\
Shorter deployment \\
times \\
Global availability \\
Reduced IT staff and \\
maintenance \\
\end{tabular} & $\begin{array}{l}\text { Security, user and identity } \\
\text { management } \\
\text { Compliance issues } \\
\text { Risk of hacking and virus } \\
\text { attacks as Internet } \\
\text { Browser is used for } \\
\text { accessing the application }\end{array}$ & \begin{tabular}{|l|} 
\\
Possible use in \\
divisions like sales, HR, \\
online training, payroll \\
etc
\end{tabular} & $\begin{array}{l}\text { Applications that } \\
\text { holds Confidential } \\
\text { data }\end{array}$ \\
\hline CaaS & \begin{tabular}{|l|} 
\\
Communications \\
as a Service \\
\end{tabular} & $\begin{array}{l}\text { Communications using a } \\
\text { client server model } \\
\text { Server can host anything from } \\
\text { phone call switching to } \\
\text { sharing online content }\end{array}$ & $\begin{array}{l}\text { Reduce costs of } \\
\text { communications }\end{array}$ & $\begin{array}{l}\text { Security needs to be } \\
\text { assessed }\end{array}$ & $\begin{array}{l}\text { For IP telephony, video } \\
\text { conference calls, Live } \\
\text { meetings etc }\end{array}$ & NA \\
\hline Maas & $\begin{array}{l}\text { Monitoring as a } \\
\text { Service }\end{array}$ & $\begin{array}{l}\text { Monitorinrg } \\
\text { servers/platforms/application } \\
\text { s hosted in Cloud } \\
\text { environment }\end{array}$ & $\begin{array}{l}\text { Better view of the } \\
\text { uptime and SLA }\end{array}$ & Additional costs & $\begin{array}{l}\text { Monitoring Cloud } \\
\text { services }\end{array}$ & NA \\
\hline ELaaS & $\begin{array}{l}\text { Education and } \\
\text { learning as a } \\
\text { service }\end{array}$ & $\begin{array}{l}\text { Providing online education in } \\
\text { cloud environment }\end{array}$ & $\begin{array}{l}\text { Reduce costs as no tutor } \\
\text { is required along with } \\
\text { room etc } \\
\text { Same course can be run } \\
\text { multiple times for users }\end{array}$ & lack of interaction & $\begin{array}{l}\text { Online Trainings } \\
\text { hosting and delivery }\end{array}$ & NA \\
\hline BPaaS & $\begin{array}{l}\text { Business- } \\
\text { Process as a } \\
\text { Service }\end{array}$ & $\begin{array}{l}\text { BPO services offered as a } \\
\text { Cloud service }\end{array}$ & $\begin{array}{l}\text { No need to install local } \\
\text { servers, platforms and } \\
\text { applications for hosting } \\
\text { Business process related } \\
\text { applications }\end{array}$ & NA & $\begin{array}{l}\text { Back office IT support } \\
\text { etc }\end{array}$ & NA \\
\hline
\end{tabular}

Figure 2: Service models summary for a Pharma X.

organizations are reliant on web-based applications to run their businesses, they require more computing resources to ensure they provide their services when they are required, but often cannot anticipate spikes in demand. Friendster's decline in popularity relative to its competitors (Facebook and Myspace) is widely believed to have partly resulted from user dissatisfaction with slow response times [3, 11]. This problem can be accommodated by cloud computing services in instances when spikes in demand fall and visitors turn away, organizations will not be lumbered with expensive resources they do not require. It is estimated that around $53 \%$ of datacentre costs relate to electricity and cooling and thus economies of scale in electricity, bandwidth, operations, staff, software and hardware can reduce costs by a factor of $5-7[13,15$, 19]. Thus, cloud computing is, in the long run, more cost effective for organizations paying by the hour for services on demand [3]. Other benefits include reduced demand for skilled labour especially when there is a shortage of skilled IT labour. In addition to cost savings, organizations can simplify the complexity of capital intensive IT investment, moving to a 'pay-asyou-go' model of IT expenditure which focuses re- 
allocation of limited resources on their core business capabilities.

\section{CONCLUSION}

Our research has demonstrated that the cloud has the potential to provide a whole range of different and more sophisticated service models which can be tailored to the organization's context and service requirements. Our exploratory study showed that while there is a strong willingness from managers for the adoption of the cloud, there are several evaluation issues that need to be carefully considered further. It is also clear that managers need to invest time and resources to the challenges of new 'digital' systems for business value.

\section{REFERENCES}

[1] Accenture 2014. http://www.accenture.com/us-en/pages/ index.aspx

[2] Amazon Web Services, L., 2006. About AWS. http://aws.amazon.com/what-is-aws

[3] Armbrust M, Fox A, Griffith R, Joseph AD, Katz R, Konwinski A, Lee G, Patterson D, Rabkin A. Stoica I, Zaharia M. A view of cloud computing. Communications of the ACM 2010; 53(4): 50-58.

http://dx.doi.org/10.1145/1721654.1721672

[4] Cai H. Customer Centric Cloud Service Model and a Case Study on Commerce as a Service. Cloud Computing, 2009. CLOUD '09. IEEE International Conference on 21-25 Sept, 2009; 57-64. http://dx.doi.org/10.1109/cloud.2009.67

[5] Craig-Wood K. What is Cloud Computing? 2010. http://www.katescomment.com/what-is-cloud-computing

[6] CRN Staff C. The 100 Coolest Cloud Computing Vendors Of 2012. http://www.crn.com/news/cloud/232602632/the-100coolest-cloud-computing-vendors-of-2012.htm;jsessionid= g3+H2RQ1RD0Dn68JuaRHTg ${ }^{* *}$.ecappj03

[7] Ellison L. Comments on Cloud Computing transcribed from Youtube 2008. http://www.youtube.com/watch?v= OFacYAI6DY0
[8]

Garfinkel SL. The Cloud Imperative, MIT Technology Review, 3rd October, 2011 http://www.technologyreview.com/ news/425623/the-cloud-imperative

[9] Google Trends, Google Trend for Utility Computing, Grid Computing, Autonomic Computing, Cloud Computing 2012 http://www.google.com/trends/?q=Utility+Computing, + Grid+C omputing, + Autonomic+Computing, Cloud+Computing\&ctab $=0$ $\&$ geo $=$ all \&date $=$ all \&sort $=0$

[10] Harvard MBA 2014. http://www.hbs.edu/mba/the-hbsdifference/Pages/default.aspx

[11] KPMG International. Clarity in the Cloud 2011. http://www.kpmg.com/AU/en/IssuesAndInsights/ArticlesPubli cations/cloud-computing/Documents/clarity-in-the-cloudbusiness-adoption.pdf

[12] Mell P, Grance T. The NIST Definition of Cloud Computing NIST Special Publication 800-145 2011. Available from http://csrc.nist.gov/publications/nistpubs/800-145/SP800145.pdf

[13] Meng S, Liu L. Enhanced Monitoring-as-a-Service for Effective Cloud Management. Computers, IEEE Transactions on Computers, (in press) 2012; 1-14.

[14] Reza M. Framework on Large Public Sector Implementation of Cloud Computing. Cloud Computing and Social Networking (ICCCSN), 2012 International Conference on 2627 April, 2012; 1-4. http://dx.doi.org/10.1109/icccsn.2012.6215749

[15] Sales Force. Company Milestones 1999. http://www. salesforce.com/company/milestones

[16] Stephanie FL, Sharma RS. Health on a Cloud: modelling digital flows in an e-Health ecosystem. Journal of Advances in Management Systems 2016; 2: 1-20.

[17] Suciu G. Cloud consulting: ERP and communication application integration in open source cloud systems. Telecommunications Forum (TELFOR) 2011; 578-581

[18] van den Heuvel W-J. Leveraging Business Process as a Service with Blueprinting. Commerce and Enterprise Computing (CEC), 2011 IEEE 13th Conference, 2011; 225. http://dx.doi.org/10.1109/cec.2011.76

[19] Venters, Will and Whitley, Edgar A. A critical review of cloud computing: researching desires and realities. Journal of Information Technology 2012; 27(3): 179-197. http://dx.doi.org/10.1057/jit.2012.17

[20] Yang H, Tate M. A Descriptive Literature Review and Classification of Cloud Computing Research, Communications of the Association for Information Systems 2012; 31(2): 36-60.

(C) 2016 Tassabehji and Hackney; Licensee Lifescience Global.

This is an open access article licensed under the terms of the Creative Commons Attribution Non-Commercial License (http://creativecommons.org/licenses/by-nc/3.0/) which permits unrestricted, non-commercial use, distribution and reproduction in any medium, provided the work is properly cited. 